OPEN ACCESS

Edited by:

Hansen Wang,

University of Toronto, Canada

Reviewed by: Daniel Tornero,

University of Barcelona, Spain

Kristine Freude,

University of Copenhagen, Denmark

*Correspondence:

Ariel Ávila

aavila@ucsc.cl

Received: 05 August 2019 Accepted: 07 November 2019 Published: 21 November 2019

Citation:

Ojeda J and Ávila A (2019) Early Actions of Neurotransmitters During Cortex Development and Maturation of Reprogrammed Neurons. Front. Synaptic Neurosci. 11:33. doi: 10.3389/fnsyn.2019.00033

\section{Early Actions of Neurotransmitters During Cortex Development and Maturation of Reprogrammed Neurons}

\author{
Jorge Ojeda and Ariel Ávila* \\ Developmental Neurobiology Unit, Biomedical Sciences Research Laboratory, Basic Sciences Department, Faculty of \\ Medicine, Universidad Católica de la Santísima Concepción, Concepción, Chile
}

The development of the brain is shaped by a myriad of factors among which neurotransmitters play remarkable roles before and during the formation and maturation of synaptic circuits. Cellular processes such as neurogenesis, morphological development, synaptogenesis and maturation of synapses are temporary and spatially regulated by the local or distal influence of neurotransmitters in the developing cortex. Thus, research on this area has contributed to the understanding of fundamental mechanisms of brain development and to shed light on the etiology of various human neurodevelopmental disorders such as autism and Rett syndrome (RTT), among others. Recently, the field of neuroscience has been shaken by an explosive advance of experimental approaches linked to the use of induced pluripotent stem cells and reprogrammed neurons. This new technology has allowed researchers for the first time to model in the lab the unique events that take place during early human brain development and to explore the mechanisms that cause synaptopathies. In this context, the role of neurotransmitters during early stages of cortex development is beginning to be re-evaluated and a revision of the state of the art has become necessary in a time when new protocols are being worked out to differentiate stem cells into functional neurons. New perspectives on reconsidering the function of neurotransmitters include opportunities for methodological advances, a better understanding of the origin of mental disorders and the potential for development of new treatments.

Keywords: neurotransmitters, hiPSC derived neurons, cortex, GABA, glycine, glutamate, neurogenesis, neurodevelopmental disorder

\section{INTRODUCTION}

The development of the brain cortex is an evolutionarily conserved process that starts during early embryonic stages and continues throughout childhood and adolescent all the way to adulthood (Kast and Levitt, 2019). In such a long process, there are plenty of events in which the developmental path can be altered and thus, the factors that influence the early stages of brain development 
can have profound effects on the functioning of an otherwise normal brain. In this context, neurotransmitters are among the most important extracellular cues that control the development of the cortex. Remarkably, these classical communication molecules have been shown to participate in a range of cellular processes that include cellular division, differentiation, neurogenesis, migration, morphological development, synapse formation, synaptic pruning and circuit maturation.

Neurotransmitters are fundamental factors involved in neuronal communication. They are well known and continue to be studied for their role at synapses mediating the transmission of information throughout the entire nervous system. In this regard, undoubtedly synapses are central for the functioning of the brain. Thus, the last 40 years have seen a tremendous advance in our understanding of the role of neurotransmitters at the synapses (Snyder, 2009). However, neurotransmitters are, now for about two decades, beginning to be recognized as pleiotropic extracellular signaling molecules with roles that span far beyond synaptic communication (Ascenzi and Bony, 2017). More in detail, neurotransmitters can act on ionotropic or metabotropic receptors, being the response mediated by the ionotropic receptors in the order of milliseconds and more than 10-times faster compared to metabotropic receptors. This difference in the speed of action relates to their intrinsic properties. While ionotropic actions are based on the flux of ions through the membrane and the subsequent change on resting membrane potential (RMP), metabotropic actions are mediated by the activation of $G$ proteins. Nevertheless, the activation of ionotropic channels can also lead to the activation of downstream signaling cascades that merge onto $\mathrm{G}$ protein-mediated signaling. This is particularly relevant during development when ionic gradients are being established and the actions of ionotropic receptors are pleiotropic.

Here, we discuss the role of the most relevant neurotransmitters $\gamma$-aminobutyric acid (GABA, glycine and glutamate) focused on the neurogenesis, and synapse development including what begins to be discovered using reprogrammed neurons. Moreover, to keep the length of this review to a reasonable extent and to appropriately cover the recent discoveries, we will focus on ionotropic receptors, the developing cerebral cortex and the models that are currently being put forward to understand this system.

\section{NON-SYNAPTIC FUNCTIONS OF NEUROTRANSMITTERS DURING BRAIN DEVELOPMENT}

Early experiments demonstrated that knocking out synaptic release machinery did not interfere with normal embryonic brain development in terms of axon targeting, layering and generation of gross morphological features (Verhage et al., 2000). However, before synapse formation, neurotransmitters are released by non-vesicular transport or through a process not requiring SNARE machinery (Demarque et al., 2002). Thus, although independently of vesicular release, we now know that neurotransmitters can have important effects in the structuring of the brain cortex.

\section{GABA $_{A}$ Receptors}

The GABA is arguably the most important neurotransmitter acting during embryonic development prior to synapse formation. Early experiments demonstrated that GABA was able to tonically activate neurons before synapse formation (Demarque et al., 2002). In line with this, early on it was found that GABA was able to inhibit DNA synthesis through the activation of $\mathrm{GABA}_{\mathrm{A}}$ receptors $\left(\mathrm{GABA}_{\mathrm{A}}\right.$; LoTurco et al., 1995). More recently, similar findings have been described on retinal progenitors where more detailed analyses have linked the effects of GABA to the increase of intracellular calcium (Wang et al., 2019), which may as well be involved in the activation of CREB signaling (Jagasia et al., 2009).

Characteristically, both excitatory and inhibitory neurons of the cortex are born away from their final place having to migrate from the ventricular and subventricular zones where they are generated. For excitatory neurons, this means radial migration while for inhibitory neurons this involves a long road ahead in a process named tangential migration. In this context, GABA receptor activation was first found to exert a chemotropic effect on main cortical neurons (Behar et al., 1996). Additionally, it has been shown that activation of $\mathrm{GABA}_{\mathrm{A}}$ regulates radial migration at birth by affecting the dynamics of intracellular calcium of migrating neurons (Wang et al., 2003; Heck et al., 2007). Likewise, activation of $\mathrm{GABA}_{\mathrm{A}}$ at the rostral migratory stream during early postnatal development has been shown to modulate cell migration leading to the formation of the Islands of Calleja (Hsieh and Puche, 2015). Using the overexpression of a sodium channel as a tool to increase excitability and the frequency of calcium transients, it was found that precocious increase of calcium spikes induced migration arrest and the generation of neural processes (Bando et al., 2016). In line with that, a complementary approach increasing the expression of the potassium chloride transporter KCC2, the major extruder of $\mathrm{Cl}^{-}$ions in mature neurons, leads to arrested morphological development of pyramidal neurons through the blockage of the excitatory action of GABA during embryonic development of the cortex (Cancedda et al., 2007). A similar role and mechanism of action involving $\mathrm{GABA}_{\mathrm{A}}$ activation was described on migratory interneurons (Cuzon et al., 2006; Bortone and Polleux, 2009). In this case, migrating interneurons were shown to be stimulated to migrate during early phases of tangential migration while, upon increased expression of KCC2, they responded to GABA with migration arrest and generation of secondary neurites (Bortone and Polleux, 2009). More detailed experiments aimed at understanding the downstream mechanisms of GABA, during morphological maturation in pyramidal cells and interneurons, have supported the notion that upon GABA receptor activation, the subsequent depolarization triggers the activation of L-type calcium channels, which ultimately affect neurite outgrowth (Maric et al., 2001; Bortone and Polleux, 2009).

On the mechanisms of GABA, a depolarization action linked to the downstream activation of voltage-dependent calcium channels surges as a transversal effect operating during 
neurogenesis, migration and morphological development of all cortical neurons (Behar et al., 1996; Maric et al., 2001; Soria and Valdeolmillos, 2002; Heck et al., 2007; Bando et al., 2016). Moreover, whenever the identity of calcium channels affected by GABA-induced depolarization has been investigated, L-type calcium channels and no others have been found to be predominantly involved (Maric et al., 2001; Bortone and Polleux, 2009; Bando et al., 2016). However, beyond calcium rise, downstream events remain poorly understood. Among possible calcium targets operating during development are calcium calmodulin-dependent kinases (Takemoto-Kimura et al., 2007) and transcription of c-Fos and BDNF (Berninger et al., 1995).

\section{Glycine Receptors}

This small amino acid neurotransmitter receptor is better known by its role in mediating synaptic transmission in the spinal cord through the activation of glycine receptors (Colin et al., 1998; Scain et al., 2010). However, alpha 2 subunit containing glycine receptors (GLRA2) are widely expressed in the developing cerebral cortex (Kuhse et al., 1991; Malosio et al., 1991; Flint et al., 1998; Avila et al., 2013b, 2014). On the other hand, in contrast to the developing spinal cord, where radial glial cells are the main source of glycine (Scain et al., 2010), in the developing cortex, glycine and taurine are both detected on immature neurons (Flint et al., 1998; Avila et al., 2013b). HPLC-based studies have quantified the neurotransmitter content in the developing cortex showing that the concentration of glycine is more than four times higher than the concentration of GABA at the embryonic day 13, while taurine concentration is even higher (Benítez-Diaz et al., 2003; Qian et al., 2014). Thus, glycine receptor-mediated signaling might have been neglected for years in favor of research on the role of GABA during brain development.

The first experiments designed to assess the functionality of cortical glycine receptors demonstrated the presence of glycine receptor-mediated currents in the cortical plate and intermediated zone, while currents were absent in the ventricular zone during late embryonic development of the rat cortex (Flint et al., 1998). However, when earlier time points were investigated, glycine elicited current was detected in new-born neurons of the ventricular zone (Noctor et al., 2004). Complementary experiments using calcium imaging as a readout of glycine receptor activation confirmed receptor functionality in the cortical plate at E17 (Young-Pearse et al., 2006) and E13 in mice (Platel et al., 2005). Importantly, calcium imaging at E13 (Platel et al., 2005) and electrophysiological recordings in the ventricular zone of the developing cortex (Noctor et al., 2004) were suggestive of a role of glycine receptors in the proliferation and differentiation of dorsal progenitors (Avila et al., 2013a). This putative role was later studied using Glra2 knock-out mice lacking the expression of the alpha 2 subunit of glycine receptors (Avila et al., 2014). In this later study, glycine receptor expression at the ventricular zone was confirmed using immunostaining, electrophysiology and calcium imaging. Interestingly, glycine receptors were found at the subventricular zone only before E15, which may explain why earlier studies performed at later time point did not find glycine receptor expression at the proliferative zones (Flint et al., 1998). Having clarified previous discrepancies on the expression of glycine receptors, detailed morphological measurements of the developing brain of knock-out mice evidenced important anatomical defects in the brain of animals lacking Glra2 gene. Absence of this gene was found to lead to moderated microcephaly arising from decreased number of upper layer excitatory neurons and to a lesser extent from fewer interneurons (Avila et al., 2014). Cellular mechanisms that were put forward included a direct control of the differentiation process of PAX6 positive progenitor cells. In animals lacking glycine receptors, PAX6 positive progenitors shifted from primarily generating TBR2 intermediate progenitors to directly generate lower layer cortical neurons in a higher proportion. This had the consequence of anticipately depleting the pool of progenitors at early embryonic stages compromising the generation of later born neurons such as upper layer cortical neurons. All this was supported by findings on the changed cleavage plane of PAX6 positive cells, increased cell cycle exit at E13, higher proportion of TBR1-TBR2 double-positive neurons at E12 and decreased numbers of CUX1 and CTIP2 positive neurons at birth (Avila et al., 2014). This later study is the most in deep study conducted on the role of glycine receptors on the neurogenesis process and formation of the brain and contributes with mechanistic insights on how glycine receptors control brain development.

Paralleling the advances on the role of GABA controlling cell migration and benefiting from the fact that cortical glycine receptors are almost exclusively formed by the alpha 2 subunit during cortical development, the use of the Glra2 knock-out mice allowed to evaluate in detail the contribution of glycine receptors to the control of cell migration. As a first approach, a study conducted in vitro, where neurons were labeled using BrdU and glycine receptors were blocked using strychnine, suggested that glycine receptors could influence radial migration in embryonic mice (Nimmervoll et al., 2011). However, it remains to be addressed if the actions detected in vitro occur in vivo. Especially considering that the results obtained using BrdU labeling might be affected by the more recently described function of glycine receptors in controlling the neurogenic process (Avila et al., 2014). On the other hand, the role of glycine receptors in controlling the migration of cortical inhibitory neurons has become clearer. Specifically, using the Glra2 knock-out mice and two-photon microscopy, it has been demonstrated that removal of glycine receptors impairs interneuron migration. In consequence, Glra2 knock-out mice have a decreased number of interneurons in the cortex, which likely generates a state of hyper-excitability in young pups (Morelli et al., 2017).

In addition to the mechanisms operating downstream receptor activation described for the actions of GABA, glycine receptors have also been shown to activate voltage gated sodium channels leading to glutamate release at E13 (Platel et al., 2005). Moreover, the activation of calcium channels by glycine receptors is coupled to the phosphorylation of myosin in migratory interneurons (Avila et al., 2013b). Nevertheless, more detailed mechanisms describing the actions of glycine receptors on the control of the neurogenesis process remain to be investigated. 


\section{Glutamate Receptors}

Glutamate is the classic excitatory neurotransmitter and the main mediator of synaptic transmission in the brain. However, evolutionary studies suggest that the original function of glutamate might have been extra synaptic (Hirai et al., 2018). In neurons, glutamate can act on ionotropic iGluR, NMDA, kinate and delta receptors as well as on metabotropic receptors at synaptic and extra-synaptic sites (Herman and Jahr, 2007; Chiu and Jahr, 2017). In general, due to the variety of subunits that can form GluA receptors, it has been difficult to probe their role during development of the mammalian central nervous system (Hirai et al., 2018). Nevertheless, during development, NMDA receptors were found to be differentially expressed in the layers of the developing cortex, concentrating their expression in the cortical plate (LoTurco et al., 1991). In fact, they were found to be completely absent from ventricular progenitor cells, which only began to express NMDA receptors somewhere after their last mitotic division. In contrast, in vivo experiments using ketamine, an NMDA receptor antagonist, demonstrated a dose-dependent reduction in the number of BrdU-labeled cells in the developing cortex suggesting that ketamine and NMDA receptor blockage can indeed inhibit cellular proliferation in neurogenic regions (Huang et al., 2015; Dong et al., 2016). In turn, NMDA receptor blockage by ketamine would be promoting the differentiation of cortical progenitors into astrocytes during late embryonic development (Huang et al., 2015). Moreover, although progenitor cells might be insensitive to any harm, new born neurons can be dramatically affected by ketamineinduced NMDA receptor blockage (Wang et al., 2017). These results are further supported by numerous studies that show that NMDA receptors play an important role in regulating proliferation and differentiation of neuronal progenitors (Luk et al., 2003; Keilhoff et al., 2004; Kitayama et al., 2004; Joo et al., 2007; Mochizuki et al., 2007; Nácher et al., 2007). Regarding AMPA and Kinate receptors, they were found to be present at the ventricular zone of the cortex and to be particularly important in controlling the neurogenesis process by signaling to progenitors to differentiate (LoTurco et al., 1995). More detailed experiments found that while activation of these receptors increased ventricular zone proliferation, it also decreased sub-ventricular zone cell proliferation with an accompanying decrease in the generation of postmitotic neurons (Haydar et al., 2000). This differential effect was observed to be dependent on AMPA/kainate receptor activation as it was blocked using CNQX. Remarkably, in human fetal neural progenitor cells (NPCs) isolated from fetal brain tissue, it was found that AMPA and not NMDA receptor activation induces neuronal differentiation (Whitney et al., 2008). Coincidently, numerous studies have confirmed a role of AMPA/kainate receptors in the control of proliferation and differentiation of neuronal progenitors in the hippocampus (Gray and Sundstrom, 1998; Bernabeu and Sharp, 2000; Bai et al., 2003; Jiang et al., 2004; Poulsen et al., 2005).

On the effects of glutamate controlling cell migration, evidence suggested early on that glutamate was even more potent than GABA as a chemotropic for migrating principal neurons acting on NMDA receptors (Behar et al., 1999).
Testing of blocking NMDA receptors showed that activation of NMDA receptor was needed for new born neurons to migrate (Komuro and Rakic, 1993; Hirai et al., 1999). Similarly, migrating interneurons were also suggested to be affected by NMDA receptor activation (Soria and Valdeolmillos, 2002; Bortone and Polleux, 2009). As expected, activation of NMDA receptor on ventricular zone derived neurons leads to a transient increase of intracellular calcium, which was linked to promotion of cell migration (Behar et al., 1999). Consequently, chelation of calcium resulted in inhibited neuronal migration (Hirai et al., 1999). Unexpectedly, NMDA agonist stimulation resulted as well in inhibition of cell migration when tested in vitro (Kihara et al., 2002). This is hypothesized to result from a narrow window of action in which NMDA receptor activation would be controlling cell migration. Remarkably, a recent study has analyzed the effects of NMDA receptor blockade on cell migration due to its clinical relevance (Yuryev et al., 2018). In vivo time-lapse imaging of the developing cerebral cortex on E14-15 embryos demonstrated that neuronal migration was strongly inhibited by the anesthetic ketamine while isoflurane had no effect. This study highlights an important consequence that may arise from the use of ketamine during pregnancy (Yuryev et al., 2018). Beyond this effect on cell migration, at this point it is important to stress that interfering with glutamate signaling during brain development has been associated with numerous neurodevelopmental disorders (Jansson and Akerman, 2014).

Non-NMDA glutamate receptors are known to be expressed in migrating cortical interneurons (Métin et al., 2000; Soria and Valdeolmillos, 2002). Specifically, migrating interneurons were shown to express calcium-permeable AMPA and kainate receptors while migrating through the intermediate zone (Métin et al., 2000; Soria and Valdeolmillos, 2002) in addition to NMDA receptors (Soria and Valdeolmillos, 2002). As expected, in this case, AMPA receptor activation was also linked to promoting cell migration since AMPA receptor blockade decreased cell motility by increasing interneuron pausing time (Bortone and Polleux, 2009). Similarly, in the case of radial migration, blocking AMPA/kainate receptors lead to enhanced extension of radial processes and reduced motility of new born neurons isolated from E14 rat embryos (Jansson et al., 2013).

\section{Other Lesser Studied Neurotransmitter Receptors With Neurodevelopmental Roles}

Normally associated with fine tuning of superior functions of the brain, serotonin can act on several serotonin receptors. They are all coupled to $\mathrm{G}$ protein except for the 5HT-3 ionotropic serotonin receptor. Consequently, the effects of serotonin on the developing cerebral cortex are almost exclusively mediated by the activation of metabotropic receptors (Vitalis and Parnavelas, 2003; Riccio et al., 2009, 2011). Despite that, the 5HT-3 receptor is widely distributed in the developing nervous system along with serotonin transporters (Tecott et al., 1995) where they influence the behavior of migratory interneurons originated at the caudal ganglionic eminence (Vitalis et al., 2007; Murthy et al., 2014). Remarkably, this neurodevelopmental function comes in anticipation of a different role that has been suggested for 5 HT -3 receptors to play in the adult brain, where it would be 
modulating interneuron activity (Morales and Bloom, 1997). This dual nature resembles the actions of GABA and glycine and seems to be a common feature of neurotransmitter-gated ion channels. Another neurontransmitter receptor, lesser studied in the context of brain development, is the nicotinic acetyl choline receptor (nAchR). This receptor is specifically activated by nicotine and thus it was studied for its potential involvement in the detrimental effects of nicotine. Specifically, it was found that $\mathrm{nAchR}$ activation induced apoptosis and cell death of hippocampal progenitor cells (Berger et al., 1998).

\section{NEUROTRANSMISSION ON MATURING REPROGRAMMED NEURONS}

\section{Lessons From Monolayer Cultures}

In the last decade, the field of neuroscience has been revolutionized by an explosive advance in the experimental strategies linked to the use of human-induced pluripotent stem cells (hiPSCs). Since the first time that patients derived cell were obtained (Dimos et al., 2008; Park et al., 2008), this new technology has been widely adopted to study the effects of mutations, assess the effects of drugs, attempt cell replacement therapies and to investigate developmental biology processes in a human context. Although obtained from reprogramming of somatic cells, hiPSCs are equivalent in every aspect to embryonic stem cells keeping their remarkable ability to differentiate into any adult cell. To date, there are several methods available to differentiate hiPSCs toward specific neuronal subtypes (Bibel et al., 2007; Farra et al., 2012; Espuny-Camacho et al., 2013; Zhang et al., 2013; Kelava and Lancaster, 2016; Liu et al., 2017; Qian et al., 2018). Despite that, generating neurons directly from fibroblasts is also possible and this could be a more appropriated approach, when attempting to model conditions with an important aging component, since age-dependent transcriptomic signatures are preserved when doing so in contrast to the differentiation induced on hiPSCs, which involves the rejuvenation of cells and the restart of the developmental process (Mertens et al., 2015). Independently of the applied methodology, a series of protein markers such as nestin, b-III tubulin, MAP2 and NeuN are used to evidence a neural cell phenotype, which does not always represent a mature state in these neuronal models (Belinsky et al., 2011; Lepski et al., 2011, 2013; Maroof et al., 2013; Prè et al., 2014). In particular, the functional maturation of hiPSCs-derived neurons is better assessed attending to their electrophysiological properties (Prè et al., 2014). Thus, time of differentiation affects the maturation of action potentials (APs), generation of sizable sodium and potassium currents, evolution of passive membrane properties and appearance of spontaneous synaptic activity (Song et al., 2012; Zhang et al., 2013; Prè et al., 2014; Kang et al., 2017). Some of the first attempts to generate human neuronal models were based on the direct conversion of hiPSCs into reprogrammed neurons, but these protocols failed to recapitulate all the functional properties of mature neurons (Qiang et al., 2011; Karow et al., 2012). In turn, a more robust generation of mature electrophysiological properties, in an even shorter time of differentiation, was reached with co-culture of hiPSCsderived neurons with glial cells (Tang et al., 2013; Zhang et al., 2013). Individually cultured hiPSCs, differentiated into mature forebrain-type neurons, showed an expected time-dependent decrease of the RMP after 48-55 days. However, evolution of this parameter was speeded up with co-culture of glial cells (Prè et al., 2014). In addition, the amplitude of the AP, the inward sodium current and the frequency of spontaneous synaptic events were enhanced even before 2 weeks of culture, when using the co-culture strategy (Tang et al., 2013; Zhang et al., 2013; Prè et al., 2014). In line with the positive effect reported when using glial cells in the differentiation of hiPSCs into neurons, a recent report evidenced that astrocyte conditioned medium (ACM) improves the functional maturation rate of neurons by hyperpolarizing the RMP and increasing their spontaneous activity (Kemp et al., 2016). A possible mechanism operating when using ACM involves the modulation of calcium currents (D’Ascenzo et al., 2006; Lepski et al., 2013; Kang et al., 2017). In particular, the pharmacological blockage of calcium channels reveals that L-type, $\mathrm{N}$-type and R-type calcium channels contribute to enhance the differentiation rate when using ACM. Remarkably, the effect of ACM is also mediated by $\mathrm{GABA}_{\mathrm{A}}$ during an early stage of differentiation (Kemp et al., 2016). Thereby, this data indicates that GABA neurotransmitter could promote the neuronal differentiation via a non-canonical mechanism of transmission.

The consolidation of functional synapses goes along with morphological changes and alterations on the gene expression pattern (Kang et al., 2017). In-depth characterization of morphology of hiPSCs-derived NPCs shows that neurite length, axon length, and the secondary and tertiary branches of dendrites were increased after 10 days of differentiation (Kang et al., 2017). With focus on the electrophysiological properties, the molecular components that determine the morphological changes of hiPSCs during differentiation into neurons have been studied by using pharmacological inhibition of ROCK GTPases (Harbom et al., 2019). However, while ROCK inhibitor accelerated the generation of complex morphology, it did not contribute to the development of mature electrophysiological activity (Harbom et al., 2019). In contrast, the phosphodiesterase inhibitor 3Isobutyl-1-methylxanthine (IBMX) was shown to increase the level of cAMP and to promote the mature morphology after 1 week of differentiation accelerating the generation of APs and increasing the amplitude of sodium, potassium and L-type calcium currents (Lepski et al., 2013). On the other hand, AP-evoked vesicular release underlies the molecular assembly of presynaptic release machinery at the CNS (Südhof, 2013). This process depends on the homeostasis and maintenance of a myriad of synaptic proteins whose signaling mechanisms have not been broadly described. Nevertheless, in essence, synaptic communication relies on regulated secretion through two pathways: synaptic vesicles (SVs) and dense-core vesicles (DCVs; Rizo and Südhof, 2012; Persoon et al., 2018). In this context, co-culture of differentiated hiPSCs-derived GABAergic neurons with glial cells evidenced both, SV and DCV markers. Moreover, calcium/SNARE dependency was observed at 50 days of in vitro culture and while DCVs showed microtubule- 
depending anterograde transport, which was markedly faster in axons than dendrites, dendrites showed similar anterograde and retrograde transport. Interestingly, while DCV secretion increased until 36 days in culture, SV secretion steadily increased for up to 50 days (Emperador Melero et al., 2017).

\section{Lessons From Cultured Organoids}

The "Fit-for-purpose" concept in the bioengineering field points out that, for example, brain organ-like structures are a model system able to provide complementary insights on cellular aspects such as morphogenesis, regionalization of specific structures, and the spatial array of circuits (arealization), as well as cell fate and specification (Jabaudon and Lancaster, 2018). Thus, cultured organoids are not expected to necessarily be able to address all developmental biology issues. Moreover, experimental reproducibility is still an important issue to take into account when drawing conclusion from data collected at different laboratories using organoids (Lancaster et al., 2013; Qian et al., 2016, 2018, 2019; Mansour et al., 2018; Giandomenico et al., 2019; Singh et al., 2019). Thus, at present, the efforts have focused on improving neural survival and the reliability of this type of culture (Eremeev et al., 2019; Giandomenico et al., 2019; Yakoub, 2019). However, guiding the development of organoids by supplementation of specific factors towards a particular lineage, or using the unguided methods relying on the intrinsic morpho-functional program and cues, offer distinct advantages to be considered (Lancaster et al., 2017; Sloan et al., 2018; Cederquist et al., 2019; Qian et al., 2019). For example, unguided methods present clear advantages to study the heterogeneity of neural progenitor subpopulations formed during the development of the brain cortex as well as for the study of the participation of neurotransmitters and their receptors during early stages of the process (Qian et al., 2019). On the other hand, recent modifications to a guided method using an air-liquid interface for the culture of organoid slices showed improved survival, enhanced self-organization, and better recapitulation in vitro of morphological and functional characteristics (Giandomenico et al., 2019). Despite reported differences between guided and unguided methods, they both are similar in the sense that both methods allow cells to undergo an intrinsic developmental program that mimic molecular (Camp et al., 2015; Quadrato et al., 2017; Amiri et al., 2018), cellular (Kadoshima et al., 2014; Qian et al., 2016; Bagley et al., 2017; Birey et al., 2017; Velasco et al., 2019) and physiological (Paşca et al., 2015; Qian et al., 2016; Birey et al., 2017) characteristics of a wide spectrum of conditions being powerful biological systems to move forward in the comprehension of early human brain cortex development (Kadoshima et al., 2014; Camp et al., 2015; Qian et al., 2016; Bershteyn et al., 2017; Birey et al., 2017; Arlotta and Paşca, 2019; Velasco et al., 2019). Remarkably, brain organoids are also beginning to be used to study synaptic transmission and the effects of neurotransmitters. Moreover, recent evidence shows that similar electrophysiological properties can be detected in both differentiated bi-dimensional and three-dimensional cultures (Chandrasekaran et al., 2017). Along this line, optimized cerebral organoids were shown to have increased abundance of neurotransmitter receptors such as glutamate, AMPA receptor
GluA1, NMDA receptor GluN1, GluN2A and GluN2B, and GABA-B receptor 1 at the mRNA and protein expression levels (Yakoub, 2019). Moreover, experiments on slices obtained from organoids showed that organoid-derived neurons have the capability of firing TTX-sensitive APs during stimulation as well as displaying prominent $\mathrm{Na}^{+}-\mathrm{K}^{+}$currents in response to voltage ramps (Qian et al., 2016). These results are all consistent with a previous report using human cortical spheroids (hCSs), in which similar electrophysiological events were recorded (Paşca et al., 2015). Also, in the latter two studies, astrocytes were found by functional recording analysis, highlighting another important feature of the method applied for the generation of their organoids (Paşca et al., 2015; Qian et al., 2016). Even more importantly, half percent of the neural population showed sEPSC (Paşca et al., 2015; Qian et al., 2016). Despite eventual discrepancies, the development of functional parameters, in organoids, progresses according to the expected neural maturation and the accompanying depolarizing-hyperpolarizing GABA switch evidenced by the reduced abundance of NKCC1 cotransporter and the enrichment of KCC2 symporter; this last one is strongly expressed in the cortical plate (CP) after 80 days of differentiation. Regarding patterns of calcium activity, while immature organoids display calcium rise in response to GABA, more mature ones respond in a higher proportion exclusively to glutamate (Qian et al., 2016). Similar findings were observed in dissociated and entire hCSs loaded with Fura-2 and Fluo- 4 probes, respectively (Lancaster et al., 2013; Paşca et al., 2015). A more refined approach, using the overexpression of GCaMP6s calcium sensor and the $\mathrm{Na}^{+}$channel blocker TTX, indicated that calcium oscillation in organoids can be used as readout of neuronal activity, as in more mature embryonic structures (Xiang et al., 2017). Likewise, pharmacological application of glutamate increased the frequency of calcium spikes in the organoid system (Lancaster et al., 2013). Also, using specific spheroids to model cortical neurons forming the pallium (glutamatergic neurons) and subpallium (GABAergic neurons), it was found that neurosteroids and allopregnanolone (an agonist of $\mathrm{GABA}_{\mathrm{A}}$ receptor) in combination with retinoic acid can increase the frequency of spontaneous calcium spikes as well (Birey et al., 2017). Taken together, these results indicate that functional neurons and neural connections are effectively established in cultured organoids and they have the ability to generate complex synaptic networks. This is more evident after long periods of culture, where cortical superior layer type neurons are born with characteristic molecular traits and functional dendritic spines (Quadrato et al., 2017; Giandomenico et al., 2019; Trujillo et al., 2019). Importantly, genetic and morphological signatures are consistent with human prefrontal cortex development (Zhong et al., 2018). Functional measurements of network activity in organoids have been performed using close-packed silicon microelectrode technology (multi-electrode array, MEA), which has offered an overview of synaptic connectivity and, in particular, it has served to measure aggregates of synaptic currents as local field potentials (LFP) helping to determine various characteristics of the generated networks. As expected, under TTX treatment, recorded AP 
and spontaneous neural firing were abolished (Quadrato et al., 2017; Trujillo et al., 2019). This result is also consistent with MEA analysis performed in air-liquid interface grown cerebral organoids (Giandomenico et al., 2019). More in detail, mathematical cross-correlation of recorded spike trains on monosynaptic connections revealed that a high number of recorded spikes (81\%) resulted from synaptic transmission non-mediated by NMDA receptor (Quadrato et al., 2017). Oscillatory network dynamic in cortical organoids has more recently been evaluated using MEA data analysis as well (Trujillo et al., 2019). In this regard, pharmacological modulation aimed at blocking glutamatergic activity and enhancing GABAergic synaptic transmission, resulted in a depressed synaptic response evidenced in the reduction of electrical activity and the loss of synchronicity (Trujillo et al., 2019). Hence, recorded calcium dynamic was also affected after pharmacological treatment with the glutamate receptor antagonist CNQX (Sakaguchi et al., 2019) while inhibition of GABAergic transmission increased the number of synchronized electrical responses (Trujillo et al., 2019). Thus, these results show that cultured organoids can display synchronous network activity resembling human cortical network development creating opportunities to study early actions of cellular neurotransmission.

\section{MODELING SYNAPTIC DYSFUNCTIONS AND MENTAL DISORDERS USING HUMAN REPROGRAMMED NEURONS}

\section{The Use of hiPSCs to Enlighten the Etiology of Neurodevelopmental Disorders and Autism}

In humans, the development of the brain is a sequential process orchestrated by dynamic patterns of gene expression and various intrinsic and extrinsic signaling molecules (Cardoso et al., 2019; Silva et al., 2019). This process start at the third week of embryonic development when the neuroectoderm folds to give shape to the neural tube (Stiles and Jernigan, 2010; Tau and Peterson, 2010). Underlying this process is intense cell proliferation, migration, differentiation and synaptogenesis. Thus, there are multiple cellular mechanisms that could be impaired and lead to impaired brain development, which also depends on sensitive and critical timeframes where brain development is more vulnerable (Meredith, 2015; Bennett et al., 2019). Modeling a condition involving neurodevelopmental disorders is a complex endeavor because the general nature of such disorders is heterogeneous and its approach requires the efficient characterization of the distinct cellular subtypes and circuits affected in correlation with the hallmark phenotypes of the pathology. Commonly, the clinical manifestations in patients occur at birth or during infancy showing alterations in several brain functions such as learning, memory, cognition and sensorimotor behavior (Korkmaz, 2011). In this context, studies using hiPSCs, in the context of the role of shank 2 and 3 and the etiology of autism spectrum disorder (ASD), supported the participation of synaptic proteins as key factors for neurodevelopmental disorders (Shcheglovitov et al., 2013; Yi et al., 2016; Vitrac and Cloëz-Tayarani, 2018; Zaslavsky et al., 2019).

We are recently starting to unravel the way of how genetic variants act in ASD patients. While many genetic factors and the environment contribute to the diversity of ASD (Prilutsky et al., 2014; Cardoso et al., 2019), the regulation of synaptic structure and function emerged as a relevant aspect linked to the etiology of ASD. Analysis of autistic patients with functional magnetic resonance imaging (fMRI) revealed reduced neuronal connectivity in brain areas related to social interaction whereas stronger neuronal connectivity was found in areas associated with repetitive behavior (Monk et al., 2009; Habela et al., 2016). Consistently, hiPSCs-derived cortical-like neurons from patients with idiopathic autism displayed reduced frequency of excitatory postsynaptic currents (EPSCs) with altered kinetics. Additionally, electrophysiological recording showed a decrease in voltage-gated sodium and fast potassium currents. Interestingly, the morphological analysis of reprogrammed neurons indicated that the number of neurites were similar to control, even though the density of synaptic protein markers was moderately reduced (Liu et al., 2017). Remarkably, the analysis of gene expression evidenced that synaptic pathways-related genes can also be increased, specially, the expression of $\mathrm{GABA}_{\mathrm{A}}$ receptor alpha 3 (GABRA3), and voltage-gated sodium type II alpha subunit (SCN2A; Mariani et al., 2015; Liu et al., 2017). In this context, with the use of organoids, it was evidenced that increased expression of $\mathrm{GABA}_{\mathrm{A}}$ exert an imbalance between glutamatergic and GABAergic neuronal fate. The overproduction of GABAergic neurons is attributable to an early increase of FOXOG1 expression, a protein that promotes the proliferation of GABAergic precursors and acquisition of GABAergic neuronal fate (Mariani et al., 2015). Furthermore, the GABAergic neuron overproduction increased GABAergic synapses with an exuberant cellular overgrowth of neurites, which was also displayed at the transcriptome analysis. In this regard, a comparative RNA-Seq study between the transcriptional pattern of gene expression of hiPSCs-derived cortical neurons from patients with idiopathic ASD and controls after 35 and 135 days after induction showed a dysregulation of genes involved in neuronal differentiation, axon guidance, cell migration, metabolism of nucleic acid, and neural region patterning (Mariani et al., 2015; DeRosa et al., 2018). In the same study, more specific findings revealed a significant decrease in the number of spontaneous calcium transients, a readout of neuronal activity and developmental expression of AMPA and NMDA receptors. Also, scratch assays showed a significantly decreased extension of neuronal processes in ASD hiPSCsderived neurons after 35 days of induction (Kruszewski, 2003; Brembeck et al., 2006; DeRosa et al., 2018). Thus, the analysis of the interaction between various altered mechanisms in a temporal context can contribute to a better understanding of neurodevelopmental disorders. In this line, a recent attempt to find a critical developmental period integrating cellular states and molecular determinants showed that transcriptional networks that produce aberrant neuronal maturation are regulated by gene modules which appeared to be accelerated in ASD NSCs (Schafer et al., 2019). Surprisingly, bypassing the NSCs stage 
by direct conversion of NSCs into cortical neurons prevented the display of neuronal ASD characteristics. These results are directly related to the intrinsic developmental changes in timing, named heterochronicity, presented during development. In connection to this particular aspect, organoids obtained from ASD patients evidenced a thinning cortical plate with a shift on migrating TBR1 positive neurons (Schafer et al., 2019). These results support the idea of a defective intrinsic transcriptional program in ASD cortical neuron development (Schafer et al., 2019). On the other hand, ASD has been related with Kleefstra syndrome (KS-ASD), a rare genetic disorder characterized by developmental delay, intellectual disability and anatomical abnormalities. KS-ASD is caused by the haploinsufficiency of the euchromatic histone lysinemethyltransferase 1 (EHMT1) gene that catalyzes the mono- and di-methylation at lys-9 position of histone $\mathrm{H} 3$, suggesting possible roles in neurodevelopment. Cortical neurons derived from KS-ASD patients showed reduced expression of EHMT1 mRNA and protein, and displayed shorter neurites as well as reduced arborization and dendritic protrusion density. In line with the defective morphology, calcium responses to acetylcholine stimuli evidenced reduced nicotinic cholinergic tone after 5 weeks of culture. Furthermore, low expression of migration and maturation genes was found. Thus, KS-ASD could be framed in the ASD umbrella and hiPSC-derived neurons could serve as another model to improve the comprehension of these mental disorders (Nagy et al., 2017).

Cultured brain organoids are able to mimic with high fidelity the spatial distribution of neural progenitors, their expansion process and their differentiation into mature neurons (Kadoshima et al., 2014; Qian et al., 2016, 2019; Birey et al., 2017; Quadrato et al., 2017; Renner et al., 2017; Xiang et al., 2017). In this line, autism is an archetypical disorder for the use of three-dimensional models because genetic alterations are often linked to the regulation of neural development leading to excitatory-inhibitory imbalance in the cortex (Mariani et al., 2015; Fatehullah et al., 2016; Nageshappa et al., 2016; Nestor et al., 2016; Choi et al., 2017). More in detail, an early study using an organoid-based three-dimensional model for ASD showed accelerated cell cycle and increased production of GABAergic interneurons (Mariani et al., 2015). Additionally, a recent report showed that in periventricular heterotopia $(\mathrm{PH})$, a common disorder characterized by neurons that do not migrate from their sites of production outward to form the cerebral cortex, organoids recapitulate the loss of structural organization of germinal zones in patients with mutations or absence of protocadherins DCHS1 and FAT4 (Klaus et al., 2019). As a consequence of this condition, increased neural nodules were observed at the equivalent ventricular zones (Klaus et al., 2019). On the other hand, modeling prenatal hypoxic injury (HI) with cultured organoids showed that transient hypoxia activated and prolonged apoptosis leading to the loss of specific outer radial glia progenitor cells (Daviaud et al., 2019). Thus, organoid models are beginning to provide important new insights in the cellular mechanisms of neurodevelopmental disorders and neurodegenerative diseases (Qian et al., 2016, 2018; Choi et al., 2017; Gabriel and Gopalakrishnan, 2017; Lee et al., 2017; Shah and Singh, 2017; Chen et al., 2019; Klaus et al., 2019; Paşca, 2019; Setia and Muotri, 2019).

\section{hiPSC and Rett Syndrome}

Rett syndrome (RTT) is one of the most severe genetic neurodevelopment disorders affecting females. The hallmarks of this disease include a normal development up to 6-18 months of age and a later deceleration of head growth and microcephaly during the RTT onset. The disorder as well is accompanied by growth retardation, weight loss and muscle hypotonia. Additionally, the onset of the syndrome is followed by impairments in cognition, social abilities and motor function (Chahrour and Zoghbi, 2007). RTT is caused in over $90 \%$ of cases by mutations in the MECP2 gene, but another minor fraction includes mutations in either FOXG1 and CDKL5 genes (Amir et al., 1999; Chahrour and Zoghbi, 2007; Amenduni et al., 2011; Guerrini and Parrini, 2012). In this context, hiPSCs-derived neurons from RTT patients expressing mutated MECP2 showed a reduced pallidin mRNA transcript. Pallidin participates in the protein interaction network of dysbindin and it is required for the biogenesis of lysosome-related organelles complex 1 (BLOC1), which was suggested to be altered in autism and schizophrenia (Larimore et al., 2013). Initial studies made use of fibroblasts from young girls expressing mutated $M E C P 2$ gene. They were used to assess and later establish the ability to reprogram somatic cells observing positive expression of $\beta$ III-Tubulin and Nestin in RTT-hiPSCs after differentiation (Hotta et al., 2009; Ananiev et al., 2011). However, analysis of fluorescence intensity indicated a reduced signal against $\beta$ III-Tubulin marker and sodium channels in RTT-hiPSCs-derived neurons compared to controls (Kim et al., 2011). This observation could be a consequence of small soma size (Cheung et al., 2011). In a successful way, the generation of in vitro neuronal models from RTT hiPSCs containing MECP2 mutations evidenced a reduced number of dendritic spines (Marchetto et al., 2010). In addition, the analysis of calcium transients in selected hiPSCs-derived neurons, whose synaptic activity response could be blocked with TTX or the glutamate receptor antagonists, showed a decreased frequency and amplitude of calcium events evidencing impaired connectivity (Marchetto et al., 2010). Likewise, these models presented defects to generate stable APs, suggesting a sodium channel impairment related to a diminished peak inward sodium currents (Farra et al., 2012). Moreover, sEPSC were reduced in amplitude compared to controls (Marchetto et al., 2010). Thus, these findings confirmed an altered neuronal network in hiPSCs-derived neurons from RTT patients. More recently, it has been demonstrated an altered KCC2 in RTT syndrome hiPSCsderived neurons. MECP2 protein regulates KCC2 expression inhibiting the RE1-silencing transcription factor, a neuronal gene repressor. This results in lower expression of KCC2 and a delayed functional switch of GABA from excitation to inhibition evidenced by GABA-evoked currents under various holding potentials (Tang et al., 2016). Interestingly, the overexpression of KCC2 or IGF-1 treatments restored the functional switch of GABA suggesting that KCC2 could be a therapeutic target to relieve RTT. 


\section{Advances on Understanding Ethanol Effects Using Human Reprogrammed Neurons}

Recently, research on extrinsic factors affecting brain development has also been facilitated by the adoption of methods based on human reprogrammed neurons. In this context, ethanol research has also been facilitated by the use of hiPSCs-derived neurons. In these cells, transcriptome studies have shown that several notch signaling pathway genes that regulate cell fate and synaptic plasticity are affected by alcohol exposure (Jensen et al., 2019). Furthermore, genes for NMDA and $\mathrm{GABA}_{\mathrm{A}}$ subunits show significantly elevated expression on human iPSCs-derived forebrain neurons after chronic treatment with $50 \mathrm{mM}$ alcohol for 7 and 21 days, respectively with daily changes (Lieberman et al., 2012, 2018). However, while electrophysiological analyses did show that $\mathrm{GABA}_{\mathrm{A}}$ - and AMPA-evoked current responses were unaffected in hiPSCs-derived neurons, a reduced amplitude of NMDA response after acute exposure to ethanol was reported (Lieberman et al., 2012). On the other hand, studies linked to the effect of ethanol as primary cause of depletion of the stem cell pool either in adult neurogenesis or prenatal development have been described (Vangipuram and Lyman, 2010; Le Maître et al., 2018). Even though a high cytotoxic concentration of ethanol could be responsible for its effect in the developing brain, these findings suggest that ethanol could impair early cellular processes in the developing CNS.

\section{PERSPECTIVES}

\section{Neurodevelopmental Function of Neurotransmitters in Light of Recent Progress Using Reprogrammed Neurons}

As it has been presented, neurotransmitters play relevant roles not only during synaptic transmission and plasticity but also ensuring the correct execution of the developmental program of the brain. Importantly, nowadays it is possible to track down the participation of neurotransmitters in the processes that originate human neuronal circuits by taking advantage of the reprogramming and differentiation of somatic cells. In this context, it was shown that manipulating the action of GABA during differentiation had a dramatic effect on the rate of neurogenic cell divisions giving rise to a homogeneous neuronal progeny (Kemp et al., 2016). This is striking because it implies that modulation of neurotransmitter systems can in principle be used to guide the differentiation process in vitro and contribute to the generation of drug screening assays. On the other hand, potential effects of interfering with neurotransmitter systems can be better assessed in reprogrammed neurons informing about the human teratogenic potential of a certain drug. This notion is further supported by studies on the effect of a NMDA receptor blocker. In particular, ketamine deleterious effects have been investigated using hiPSCsderived neurons showing how new born neurons can be dramatically affected by ketamine-induced NMDA receptor blockage (Wang et al., 2017).

\section{Using Reprogrammed Neurons for Modeling Neurodevelopmental Disorders}

Early adoption of the use of reprogrammed neurons for the modeling of neurodevelopmental disorders leads to great success in recapitulating some of the most important characteristics of the disorder of interest (Espuny-Camacho et al., 2013; Lancaster et al., 2013). In fact, the use of iPSC-derived neurons in research conducted to understand the involvement of synaptic dysfunctions in the etiology of autism has already inspired new therapeutic interventions for neurodevelopmental disorders (Darville et al., 2016). However, it has been evidenced that the methodology needs to be advanced in order to reduce the experimental variability or else only the most extreme phenotypes of the disease could be reproduced (Sandoe and Eggan, 2013; Brennand et al., 2015). More recently, reprogramming methods have been standardized to the point where variability is truly convening the inherent variability found on individuals from where the cells were obtained (Kilpinen et al., 2017). Nevertheless, approaches have varied when attempting differentiating hiPSCs into neurons (Dimos et al., 2008; Espuny-Camacho et al., 2013; Lancaster et al., 2013; Kemp et al., 2016). In this particular, our research on the role of neurotransmitters during cerebral cortical development has made us wonder how some important developmental signals and events are not being considered when attempting to model a disease phenotype. For instance, manipulating GABA signaling was shown to dramatically speed up the differentiation process directing it to a synchronized more mature inhibitory phenotype (Kemp et al., 2016). Moreover, in the process there was a synchronized maturation of neuronal progenitors which differs substantially from the timely controlled generation of each cortical cell type occurring during normal corticogenesis. Along the same line, commercially available differentiation media and reagents have been optimized in order to decrease the culture time needed to obtain mature neuronal activity bypassing normal developmental processes and manipulating the concentration of neurotransmitters (Bardy et al., 2015). As a consequence, while improved differentiation protocols can help to understand human-specific mechanisms of disease, they can also be the source of important experimental artifacts.

\section{AUTHOR CONTRIBUTIONS}

JO and AÁ both equally contributed to the conception, design, drafting and revising of the work. Consequently, JO and AÁ provided approval for publication of the content and agree to be accountable for all aspects of the work.

\section{FUNDING}

JO is funded by internal funds of the "Vicerrectoría de Investigación y Postgrados (VRIP)" of the Universidad Católica de la Santísima Concepción. AÁ is funded by Comisión Nacional de Investigación Científica y Tecnológica (CONICYT)+PAI+ CONVOCATORIA NACIONAL SUBVENCIÓN A INSTALACIÓN EN LA ACADEMIA CONVOCATORIA AÑO 2018 + Grant number: PAI77180086. 


\section{REFERENCES}

Amenduni, M., De Filippis, R., Cheung, A. Y. L., Disciglio, V., Epistolato, M. C., Ariani, F., et al. (2011). IPS cells to model CDKL5-related disorders. Eur. J. Hum. Genet. 19, 1246-1255. doi: 10.1038/ejhg.2011.131

Amiri, A., Coppola, G., Scuderi, S., Wu, F., Roychowdhury, T., Liu, F., et al. (2018). Transcriptome and epigenome landscape of human cortical development modeled in organoids. Science 362:eaat6720. doi: 10.1126/science.aat6720

Amir, R. E., Van den Veyver, I. B., Wan, M., Tran, C. Q., Francke, U., and Zoghbi, H. Y. (1999). Rett syndrome is caused by mutations in X-linked MECP2, encoding methyl- CpG-binding protein 2. Nat. Genet. 23, 185-188. doi: $10.1038 / 13810$

Ananiev, G., Williams, E. C., Li, H., and Chang, Q. (2011). Isogenic pairs of wild type and mutant induced pluripotent stem cell (iPSC) lines from rett syndrome patients as in vitro disease model. PLoS One 6:e25255. doi: 10.1371/journal. pone. 0025255

Arlotta, P., and Paşca, S. P. (2019). Cell diversity in the human cerebral cortex: from the embryo to brain organoids. Curr. Opin. Neurobiol. 56, 194-198. doi: 10.1016/j.conb.2019.03.001

Ascenzi, M., and Bony, G. (2017). The building of the neocortex with non-hyperpolarizing neurotransmitters. Dev. Neurobiol. 77, 1023-1037. doi: 10.1002/dneu.22495

Avila, A., Nguyen, L., and Rigo, J.-M. (2013a). Glycine receptors and brain development. Front. Cell. Neurosci. 7:184. doi: 10.3389/fncel.2013.00184

Avila, A., Vidal, P. M., Dear, T. N., Harvey, R., Rigo, J. M., and Nguyen, L. (2013b). Glycine receptor $\alpha 2$ subunit activation promotes cortical interneuron migration. Cell Rep. 4, 738-750. doi: 10.1016/j.celrep.2013.07.016

Avila, A., Vidal, P. M., Tielens, S., Morelli, G., Laguesse, S., Harvey, R. J., et al. (2014). Glycine receptors control the generation of projection neurons in the developing cerebral cortex. Cell Death Differ. 21, 1696-1708. doi: 10.1038/cdd. 2014.75

Bagley, J. A., Reumann, D., Bian, S., Lévi-Strauss, J., and Knoblich, J. A. (2017). Fused cerebral organoids model interactions between brain regions. Nat. Methods 14, 743-751. doi: 10.1038/nmeth.4304

Bai, F., Bergeron, M., and Nelson, D. L. (2003). Chronic AMPA receptor potentiator (LY451646) treatment increases cell proliferation in adult rat hippocampus. Neuropharmacology 44, 1013-1021. doi: 10.1016/s00283908(03)00104-7

Bando, Y., Irie, K., Shimomura, T., Umeshima, H., Kushida, Y., Kengaku, M., et al. (2016). Control of spontaneous $\mathrm{Ca}^{2+}$ transients is critical for neuronal maturation in the developing neocortex. Cereb. Cortex 26, 106-117. doi: 10.1093/cercor/bhu180

Bardy, C., van den Hurk, M., Eames, T., Marchand, C., Hernandez, R. V., Kellogg, M., et al. (2015). Neuronal medium that supports basic synaptic functions and activity of human neurons in vitro. Proc. Natl. Acad. Sci. U S A 112, E2725-E2734. doi: 10.1073/pnas.1504393112

Behar, T. N., Li, Y. X., Tran, H. T., Ma, W., Dunlap, V., Scott, C., et al. (1996). GABA stimulates chemotaxis and chemokinesis of embryonic cortical neurons via calcium-dependent mechanisms. J. Neurosci. 16, 1808-1818. doi: 10.1523/jneurosci.16-05-01808.1996

Behar, T. N., Scott, C. A., Greene, C. L., Wen, X., Smith, S. V., Maric, D., et al. (1999). Glutamate acting at NMDA receptors stimulates embryonic cortical neuronal migration. J. Neurosci. 19, 4449-4461. doi: 10.1523/jneurosci.19-1104449.1999

Belinsky, G. S., Moore, A. R., Short, S. M., Rich, M. T., and Antic, S. D. (2011). Physiological properties of neurons derived from human embryonic stem cells using a dibutyryl cyclic AMP-based protocol. Stem Cells Dev. 20, 1733-1746. doi: $10.1089 / \mathrm{scd} .2010 .0501$

Benítez-Diaz, P., Miranda-Contreras, L., Mendoza-Briceño, R. V., PeñaContreras, Z., and Palacios-Prü, E. (2003). Prenatal and postnatal contents of amino acid neurotransmitters in mouse parietal cortex. Dev. Neurosci. 25, 366-374. doi: 10.1159/000073514

Bennett, K. P., Brown, E. M., Santos, H. D. L., Poegel, M., Kiehl, T. R., Patton, E. W., et al. (2019). Identifying windows of susceptibility by temporal gene analysis. Sci. Rep. 9:2740. doi: 10.1038/s41598-019-39318-8

Berger, F., Gage, F. H., and Vijayaraghavan, S. (1998). Nicotinic receptorinduced apoptotic cell death of hippocampal progenitor cells. J. Neurosci. 18, 6871-6881. doi: 10.1523/jneurosci.18-17-06871.1998
Bernabeu, R., and Sharp, F. R. (2000). NMDA and AMPA/kainate glutamate receptors modulate dentate neurogenesis and CA3 synapsin-I in normal and ischemic hippocampus. J. Cereb. Blood Flow Metab. 20, 1669-1680. doi: 10.1097/00004647-200012000-00006

Berninger, B., Marty, S., Zafra, F., da Penha Berzaghi, M., Thoenen, H., and Lindholm, D. (1995). GABAergic stimulation switches from enhancing to repressing BDNF expression in rat hippocampal neurons during maturation in vitro. Development 121, 2327-2335.

Bershteyn, M., Nowakowski, T. J., Pollen, A. A., Di Lullo, E., Nene, A., WynshawBoris, A., et al. (2017). Human iPSC-derived cerebral organoids model cellular features of lissencephaly and reveal prolonged mitosis of outer radial glia. Cell Stem Cell 20, 435.e4-449.e4. doi: 10.1016/j.stem.2016.12.007

Bibel, M., Richter, J., Lacroix, E., and Barde, Y. A. (2007). Generation of a defined and uniform population of CNS progenitors and neurons from mouse embryonic stem cells. Nat. Protoc. 2, 1034-1043. doi: 10.1038/nprot.2007.147

Birey, F., Andersen, J., Makinson, C. D., Islam, S., Wei, W., Huber, N., et al. (2017). Assembly of functionally integrated human forebrain spheroids. Nature 545 54-59. doi: 10.1038/nature22330

Bortone, D., and Polleux, F. (2009). KCC2 expression promotes the termination of cortical interneuron migration in a voltage-sensitive calcium-dependent manner. Neuron 62, 53-71. doi: 10.1016/j.neuron.2009.01.034

Brembeck, F. H., Rosário, M., and Birchmeier, W. (2006). Balancing cell adhesion and Wnt signaling, the key role of $\beta$-catenin. Curr. Opin. Genet. Dev. 16, 51-59. doi: 10.1016/j.gde.2005.12.007

Brennand, K. J., Marchetto, M. C., Benvenisty, N., Brüstle, O., Ebert, A., Izpisua Belmonte, J. C., et al. (2015). Creating patient-specific neural cells for the in vitro study of brain disorders. Stem Cell Reports 5, 933-945. doi: 10.1016/j. stemcr.2015.10.011

Camp, J. G., Badsha, F., Florio, M., Kanton, S., Gerber, T., Wilsch-Bräuninger, M., et al. (2015). Human cerebral organoids recapitulate gene expression programs of fetal neocortex development. Proc. Natl. Acad. Sci. U S A 112, 15672-15677. doi: $10.1073 /$ pnas. 1520760112

Cancedda, L., Fiumelli, H., Chen, K., and Poo, M. (2007). Excitatory GABA action is essential for morphological maturation of cortical neurons in vivo J. Neurosci. 27, 5224-5235. doi: 10.1523/jneurosci.5169-06.2007

Cardoso, A. R., Lopes-marques, M., Silva, R. M., Serrano, C., Amorim, A., Prata, M. J., et al. (2019). Essential genetic findings in neurodevelopmental disorders. Hum. Genomics 13:31. doi: 10.1186/s40246-019-0216-4

Cederquist, G. Y., Asciolla, J. J., Tchieu, J., Walsh, R. M., Cornacchia, D., Resh, M. D., et al. (2019). Specification of positional identity in forebrain organoids. Nat. Biotechnol. 37, 436-444. doi: 10.1038/s41587-0190085-3

Chahrour, M., and Zoghbi, H. Y. (2007). The story of Rett syndrome: from clinic to neurobiology. Neuron 56, 422-437. doi: 10.1016/j.neuron.2007.10.001

Chandrasekaran, A., Avci, H. X., Ochalek, A., Rösingh, L. N., Molnár, K., László, L., et al. (2017). Comparison of $2 \mathrm{D}$ and $3 \mathrm{D}$ neural induction methods for the generation of neural progenitor cells from human induced pluripotent stem cells. Stem Cell Res. 25, 139-151. doi: 10.1016/j.scr.2017.10.010

Chen, H. I., Song, H., and Ming, G. L. (2019). Applications of human brain organoids to clinical problems. Dev. Dyn. 248, 53-64. doi: 10.1002/dvdy.24662

Cheung, A. Y. L., Horvath, L. M., Grafodatskaya, D., Pasceri, P., Weksberg, R., Hotta, A., et al. (2011). Isolation of MECP2-null Rett Syndrome patient hiPS cells and isogenic controls through X-chromosome inactivation. Hum. Mol. Genet. 20, 2103-2115. doi: 10.1093/hmg/ddr093

Chiu, D. N., and Jahr, C. E. (2017). Extracellular glutamate in the nucleus accumbens is nanomolar in both synaptic and non-synaptic compartments. Cell Rep. 18, 2576-2583. doi: 10.1016/j.celrep.2017.02.047

Choi, H., Song, J., Park, G., and Kim, J. (2017). Modeling of autism using organoid technology. Mol. Neurobiol. 54, 7789-7795. doi: 10.1007/s12035-016-0274-8

Colin, I., Rostaing, P., Augustin, A., and Triller, A. (1998). Localization of components of glycinergic synapses during rat spinal cord development. J. Comp. Neurol. 398, 359-372. doi: 10.1002/(sici)10969861(19980831)398:3<359::aid-cne5>3.3.co;2-9

Cuzon, V. C., Yeh, P. W., Cheng, Q., and Yeh, H. H. (2006). Ambient GABA promotes cortical entry of tangentially migrating cells derived from the medial ganglionic eminence. Cereb. Cortex 16, 1377-1388. doi: 10.1093/cercor/bhj084

D’Ascenzo, M., Piacentini, R., Casalbore, P., Budoni, M., Pallini, R., Azzena, G. B., et al. (2006). Role of L-type $\mathrm{Ca}^{2+}$ channels in neural stem/progenitor cell 
differentiation. Eur. J. Neurosci. 23, 935-944. doi: 10.1111/j.1460-9568.2006. 04628.x

Darville, H., Poulet, A., Rodet-Amsellem, F., Chatrousse, L., Pernelle, J., Boissart, C., et al. (2016). Human pluripotent stem cell-derived cortical neurons for high throughput medication screening in autism: a proof of concept study in SHANK3 haploinsufficiency syndrome. EBioMedicine 9, 293-305. doi: 10.1016/j.ebiom.2016.05.032

Daviaud, N., Chevalier, C., Friedel, R. H., and Zou, H. (2019). Distinct vulnerability and resilience of human neuroprogenitor subtypes in cerebral organoid model of prenatal hypoxic injury. Front. Cell. Neurosci. 13:336. doi: 10.3389/fncel. 2019.00336

Demarque, M., Represa, A., Becq, H., Khalilov, I., Ben-Ari, Y., and Aniksztejn, L. (2002). Paracrine intercellular communication by a $\mathrm{Ca}^{2+}$ - and SNAREindependent release of GABA and glutamate prior to synapse formation. Neuron 36, 1051-1061. doi: 10.1016/s0896-6273(02)01053-x

DeRosa, B. A., El Hokayem, J., Artimovich, E., Garcia-Serje, C., Phillips, A. W., Van Booven, D., et al. (2018). Convergent pathways in idiopathic autism revealed by time course transcriptomic analysis of patient-derived neurons. Sci. Rep. 8:8423. doi: 10.1038/s41598-018-26495-1

Dimos, J. T., Rodolfa, K. T., Niakan, K. K., Weisenthal, L. M., Mitsumoto, H., Chung, W., et al. (2008). Induced pluripotent stem cells generated from patients with ALS can be differentiated into motor neurons. Science 321, 1218-1221. doi: $10.1126 /$ science. 1158799

Dong, C., Rovnaghi, C. R., and Anand, K. J. S. (2016). Ketamine exposure during embryogenesis inhibits cellular proliferation in rat fetal cortical neurogenic regions. Acta Anaesthesiol. Scand. 60, 579-587. doi: 10.1111/aas.12689

Emperador Melero, J., Nadadhur, A. G., Schut, D., Weering, J. V., Heine, V. M., Toonen, R. F., et al. (2017). Differential maturation of the two regulated secretory pathways in human iPSC-derived neurons. Stem Cell Reports 8, 659-672. doi: 10.1016/j.stemcr.2017.01.019

Eremeev, A. V., Volovikov, E. A., Shuvalova, L. D., Davidenko, A. V., Khomyakova, E. A., Bogomiakova, M. E., et al. (2019). "Necessity is the mother of invention" or inexpensive, reliable and reproducible protocol for generating organoids. Biochemistry 84, 321-328. doi: 10.1134/S0006297919030143

Espuny-Camacho, I., Michelsen, K. A., Gall, D., Linaro, D., Hasche, A., Bonnefont, J., et al. (2013). Pyramidal neurons derived from human pluripotent stem cells integrate efficiently into mouse brain circuits in vivo. Neuron 77 , 440-456. doi: 10.1016/j.neuron.2012.12.011

Farra, N., Zhang, W. B., Pasceri, P., Eubanks, J. H., Salter, M. W., and Ellis, J. (2012). Rett syndrome induced pluripotent stem cell-derived neurons reveal novel neurophysiological alterations. Mol. Psychiatry 17, 1261-1271. doi: $10.1038 / \mathrm{mp} .2011 .180$

Fatehullah, A., Tan, S. H., and Barker, N. (2016). Organoids as an in vitro model of human development and disease. Nat. Cell Biol. 18, 246-254. doi: $10.1038 / \mathrm{ncb} 3312$

Flint, A. C., Liu, X., and Kriegstein, A. R. (1998). Nonsynaptic glycine receptor activation during early neocortical development. Neuron 20, 43-53. doi: $10.1016 / \mathrm{s} 0896-6273(00) 80433-\mathrm{x}$

Gabriel, E., and Gopalakrishnan, J. (2017). Generation of iPSC-derived human brain organoids to model early neurodevelopmental disorders. J. Vis. Exp. 14:122. doi: $10.3791 / 55372$

Giandomenico, S. L., Mierau, S. B., Gibbons, G. M., Wenger, L. M. D., Masullo, L., Sit, T., et al. (2019). Cerebral organoids at the air-liquid interface generate diverse nerve tracts with functional output. Nat. Neurosci. 22, 669-679. doi: 10.1038/s41593-019-0350-2

Gray, W. P., and Sundstrom, L. E. (1998). Kainic acid increases the proliferation of granule cell progenitors in the dentate gyrus of the adult rat. Brain Res. 790, 52-59. doi: 10.1016/s0006-8993(98)00030-4

Guerrini, R., and Parrini, E. (2012). Epilepsy in Rett syndrome and CDKL5- and FOXG1-gene-related encephalopathies. Epilepsia 53, 2067-2078. doi: 10.1111/j. 1528-1167.2012.03656.x

Habela, C. W., Song, H., and Ming, G. L. (2016). Modeling synaptogenesis in schizophrenia and autism using human iPSC derived neurons. Mol. Cell. Neurosci. 73, 52-62. doi: 10.1016/j.mcn.2015.12.002

Harbom, L. J., Rudisill, T. L., Michel, N., Litwa, K. A., Beenhakker, M. P., and McConnell, M. J. (2019). The effect of rho kinase inhibition on morphological and electrophysiological maturity in iPSC-derived neurons. Cell Tissue Res. 375, 641-654. doi: 10.1007/s00441-018-2942-7
Haydar, T. F., Wang, F., Schwartz, M. L., and Rakic, P. (2000). Differential modulation of proliferation in the neocortical ventricular and subventricular zones. J. Neurosci. 20, 5764-5774. doi: 10.1523/jneurosci.20-15-05764.2000

Heck, N., Kilb, W., Reiprich, P., Kubota, H., Furukawa, T., Fukuda, A., et al. (2007). GABA-A receptors regulate neocortical neuronal migration in vitro and in vivo. Cereb. Cortex 17, 138-148. doi: 10.1093/cercor/bhj135

Herman, M. A., and Jahr, C. E. (2007). Extracellular glutamate concentration in hippocampal slice. J. Neurosci. 27, 9736-9741. doi: 10.1523/jneurosci.300907.2007

Hirai, S., Hotta, K., and Okado, H. (2018). Developmental roles and evolutionary significance of AMPA-type glutamate receptors. Bioessays 40:e1800028. doi: 10.1002/bies.201800028

Hirai, K., Yoshioka, H., Kihara, M., Hasegawa, K., Sakamoto, T., Sawada, T., et al. (1999). Inhibiting neuronal migration by blocking NMDA receptors in the embryonic rat cerebral cortex: a tissue culture study. Dev. Brain Res. 114, 63-67. doi: 10.1016/s0165-3806(99)00019-x

Hotta, A., Cheung, A. Y. L., Farra, N., Vijayaragavan, K., Séguin, C. A., Draper, J. S., et al. (2009). Isolation of human iPS cells using EOS lentiviral vectors to select for pluripotency. Nat. Methods 6, 370-376. doi: 10.1038/nmeth.1325

Hsieh, Y.-C., and Puche, A. C. (2015). GABA modulation of SVZ-derived progenitor ventral cell migration. Dev. Neurobiol. 75, 791-804. doi: 10.1002/dneu.22249

Huang, H., Liu, L., Li, B., Zhao, P.-P., Xu, C.-M., Zhu, Y.-Z., et al. (2015). Ketamine interferes with the proliferation and differentiation of neural stem cells in the subventricular zone of neonatal rats. Cell. Physiol. Biochem. 35, 315-325. doi: $10.1159 / 000369698$

Jabaudon, D., and Lancaster, M. (2018). Exploring landscapes of brain morphogenesis with organoids. Development 145:dev172049. doi: 10.1242/dev. 172049

Jagasia, R., Steib, K., Englberger, E., Herold, S., Faus-Kessler, T., Saxe, M., et al. (2009). GABA-cAMP response element-binding protein signaling regulates maturation and survival of newly generated neurons in the adult hippocampus. J. Neurosci. 29, 7966-7977. doi: 10.1523/jneurosci.1054-09.2009

Jansson, L. C., and Akerman, K. E. (2014). The role of glutamate and its receptors in the proliferation, migration, differentiation and survival of neural progenitor cells. J. Neural Transm. 121, 819-836. doi: 10.1007/s00702-014-1174-6

Jansson, L. C., Louhivuori, L., Wigren, H.-K., Nordström, T., Louhivuori, V., Castrén, M. L., et al. (2013). Effect of glutamate receptor antagonists on migrating neural progenitor cells. Eur. J. Neurosci. 37, 1369-1382. doi: $10.1111 /$ ejn.12152

Jensen, K. P., Lieberman, R., Kranzler, H. R., Gelernter, J., Clinton, K., and Covault, J. (2019). Alcohol-responsive genes identified in human iPSC-derived neural cultures. Transl. Psychiatry 9:96. doi: 10.1038/s41398-019-0426-5

Jiang, W., Wolfe, K., Xiao, L., Zhang, Z.-J., Huang, Y.-G., and Zhang, X. (2004). Ionotropic glutamate receptor antagonists inhibit the proliferation of granule cell precursors in the adult brain after seizures induced by pentylenetrazol. Brain Res. 1020, 154-160. doi: 10.1016/j.brainres.2004.06.028

Joo, J.-Y., Kim, B.-W., Lee, J.-S., Park, J.-Y., Kim, S., Yun, Y.-J., et al. (2007) Activation of NMDA receptors increases proliferation and differentiation of hippocampal neural progenitor cells. J. Cell Sci. 120, 1358-1370. doi: $10.1242 /$ jcs. 002154

Kadoshima, T., Sakaguchi, H., Nakano, T., Soen, M., Ando, S., Eiraku, M., et al. (2014). Erratum: self-organization of axial polarity, inside-out layer pattern and species-specific progenitor dynamics in human ES cell-derived neocortex (Proceedings of the National Academy of Sciences of the United States of America (2013) 110 (20284-20289) D. Proc. Natl. Acad. Sci. U S A 111:7498. doi: 10.1073/pnas.1407159111

Kang, S., Chen, X., Gong, S., Yu, P., Yau, S., Su, Z., et al. (2017). Characteristic analyses of a neural differentiation model from iPSC-derived neuron according to morphology, physiology, and global gene expression pattern. Sci. Rep. 7:12233. doi: 10.1038/s41598-017-12452-x

Karow, M., Sánchez, R., Schichor, C., Masserdotti, G., Ortega, F., Heinrich, C., et al. (2012). Reprogramming of pericyte-derived cells of the adult human brain into induced neuronal cells. Cell Stem Cell 11, 471-476. doi: 10.1016/j.stem.2012. 07.007

Kast, R. J., and Levitt, P. (2019). Precision in the development of neocortical architecture: from progenitors to cortical networks. Prog. Neurobiol. 175, 77-95. doi: 10.1016/j.pneurobio.2019.01.003 
Keilhoff, G., Bernstein, H.-G., Becker, A., Grecksch, G., and Wolf, G. (2004). Increased neurogenesis in a rat ketamine model of schizophrenia. Biol. Psychiatry 56, 317-322. doi: 10.1016/j.biopsych.2004.06.010

Kelava, I., and Lancaster, M. A. (2016). Stem cell models of human brain development. Cell Stem Cell 18, 736-748. doi: 10.1016/j.stem.2016.05.022

Kemp, P. J., Rushton, D. J., Yarova, P. L., Schnell, C., Geater, C., Hancock, J. M., et al. (2016). Improving and accelerating the differentiation and functional maturation of human stem cell-derived neurons: role of extracellular calcium and GABA. J. Physiol. 594, 6583-6594. doi: 10.1113/jp270655

Kihara, M., Yoshioka, H., Hirai, K., Hasegawa, K., Kizaki, Z., and Sawada, T. (2002). Stimulation of N-methyl-d-aspartate (NMDA) receptors inhibits neuronal migration in embryonic cerebral cortex: a tissue culture study. Dev. Brain Res. 138, 195-198. doi: 10.1016/s0165-3806(02)00490-x

Kilpinen, H., Goncalves, A., Leha, A., Afzal, V., Alasoo, K., Ashford, S., et al. (2017). Common genetic variation drives molecular heterogeneity in human iPSCs. Nature 546, 370-375. doi: 10.1038/nature22403

Kim, K.-Y., Hysolli, E., and Park, I.-H. (2011). Neuronal maturation defect in induced pluripotent stem cells from patients with Rett syndrome. Proc. Natl. Acad. Sci. U S A 108, 14169-14174. doi: 10.1073/pnas.1018979108

Kitayama, T., Yoneyama, M., Tamaki, K., and Yoneda, Y. (2004). Regulation of neuronal differentiation byN-methyl-D-aspartate receptors expressed in neural progenitor cells isolated from adult mouse hippocampus. J. Neurosci. Res. 76, 599-612. doi: 10.1002/jnr.20095

Klaus, J., Kanton, S., Kyrousi, C., Ayo-Martin, A. C., Di Giaimo, R., Riesenberg, S., et al. (2019). Altered neuronal migratory trajectories in human cerebral organoids derived from individuals with neuronal heterotopia. Nat. Med. 25, 561-568. doi: 10.1038/s41591-019-0371-0

Komuro, H., and Rakic, P. (1993). Modulation of neuronal migration by NMDA receptors. Science 260, 95-97. doi: 10.1126/science. 8096653

Korkmaz, B. (2011). Theory of mind and neurodevelopmental disorders of childhood. Pediatr. Res. 69, 101R-108R. doi: 10.1203/pdr.0b013e318212c177

Kruszewski, M. (2003). Labile iron pool: the main determinant of cellular response to oxidative stress. Mutat. Res. 531, 81-92. doi: 10.1016/j.mrfmmm.2003. 08.004

Kuhse, J., Kuryatov, A., Maulet, Y., Malosio, M. L., Schmieden, V., and Betz, H. (1991). Alternative splicing generates two isoforms of the $\alpha 2$ subunit of the inhibitory glycine receptor. FEBS Lett. 283, 73-77. doi: 10.1016/00145793(91)80557-j

Lancaster, M. A., Corsini, N. S., Wolfinger, S., Gustafson, E. H., Phillips, A. W., Burkard, T. R., et al. (2017). Guided self-organization and cortical plate formation in human brain organoids. Nat. Biotechnol. 35, 659-666. doi: $10.1038 /$ nbt.3906

Lancaster, M. A., Renner, M., Martin, C. A., Wenzel, D., Bicknell, L. S., Hurles, M. E., et al. (2013). Cerebral organoids model human brain development and microcephaly. Nature 501, 373-379. doi: 10.1038/nature 12517

Larimore, J., Ryder, P. V., Kim, K. Y., Ambrose, L. A., Chapleau, C., Calfa, G., et al. (2013). MeCP2 regulates the synaptic expression of a Dysbindin-BLOC1 network component in mouse brain and human induced pluripotent stem cell-derived neurons. PLoS One 8:e65069. doi: 10.1371/journal.pone.0065069

Le Maître, T. W., Dhanabalan, G., Bogdanovic, N., Alkass, K., and Druid, H. (2018). Effects of alcohol abuse on proliferating cells, stem/progenitor cells, and immature neurons in the adult human hippocampus. Neuropsychopharmacology 43, 690-699. doi: 10.1038/npp.2017.251

Lee, C. T., Bendriem, R. M., Wu, W. W., and Shen, R. F. (2017). 3D brain Organoids derived from pluripotent stem cells: promising experimental models for brain development and neurodegenerative disorders. J. Biomed. Sci. 24:59. doi: 10.1186/s12929-017-0362-8

Lepski, G., Jannes, C. E., Nikkhah, G., and Bischofberger, J. (2013). cAMP promotes the differentiation of neural progenitor cells in vitro via modulation of voltage-gated calcium channels. Front. Cell. Neurosci. 7:155. doi: $10.3389 /$ fncel.2013.00155

Lepski, G., Maciaczyk, J., Jannes, C. E., Maciaczyk, D., Bischofberger, J., and Nikkhah, G. (2011). Delayed functional maturation of human neuronal progenitor cells in vitro. Mol. Cell. Neurosci. 47, 36-44. doi: 10.1016/j.men.2011. 02.011

Lieberman, R., Kranzler, H. R., Levine, E. S., and Covault, J. (2018). Examining the effects of alcohol on GABA A receptor mRNA expression and function in neural cultures generated from control and alcohol dependent donor induced pluripotent stem cells. Alcohol 66, 45-53. doi: 10.1016/j.alcohol.2017.08.005

Lieberman, R., Levine, E. S., Kranzler, H. R., Abreu, C., and Covault, J. (2012). Pilot study of iPS-derived neural cells to examine biologic effects of alcohol on human neurons in vitro. Alcohol. Clin. Exp. Res. 36, 1678-1687. doi: 10.1111/j. 1530-0277.2012.01792.x

Liu, X., Campanac, E., Cheung, H. H., Ziats, M. N., Canterel-Thouennon, L., Raygada, M., et al. (2017). Idiopathic autism: cellular and molecular phenotypes in pluripotent stem cell-derived neurons. Mol. Neurobiol. 54, 4507-4523. doi: 10.1007/s12035-016-9961-8

LoTurco, J. J., Owens, D. F., Heath, M. J., Davis, M. B., and Kriegstein, A. R. (1995). GABA and glutamate depolarize cortical progenitor cells and inhibit DNA synthesis. Neuron 15, 1287-1298. doi: 10.1016/0896-6273(95)90008-x

LoTurco, J., Wanton, G., and Kriegstein, R. (1991). Initial expression and endogenous activation of NMDA channels in early neocortical development. J. Neurosci. 11, 792-799. doi: 10.1523/jneurosci.11-03-00792.1991

Luk, K. C., Kennedy, T. E., and Sadikot, A. F. (2003). Glutamate promotes proliferation of striatal neuronal progenitors by an NMDA receptormediated mechanism. J. Neurosci. 23, 2239-2250. doi: 10.1523/jneurosci.23-0602239.2003

Malosio, M. L., Marquèze-Pouey, B., Kuhse, J., and Betz, H. (1991). Widespread expression of glycine receptor subunit mRNAs in the adult and developing rat brain. EMBO J. 10, 2401-2409. doi: 10.1002/j.1460-2075.1991.tb07779.x

Mansour, A. A., Gonçalves, J. T., Bloyd, C. W., Li, H., Fernandes, S., Quang, D., et al. (2018). An in vivo model of functional and vascularized human brain organoids. Nat. Biotechnol. 36, 432-441. doi: 10.1038/nbt.4127

Marchetto, M. C. N., Carromeu, C., Acab, A., Yu, D., Yeo, G. W., Mu, Y., et al. (2010). A model for neural development and treatment of rett syndrome using human induced pluripotent stem cells. Cell 143, 527-539. doi: 10.1016/j.cell. 2010.10.016

Mariani, J., Coppola, G., Zhang, P., Abyzov, A., Provini, L., Tomasini, L., et al. (2015). FOXG1-dependent dysregulation of GABA/glutamate neuron differentiation in autism spectrum disorders. Cell 162, 375-390. doi: 10.1016/j. cell.2015.06.034

Maric, D., Liu, Q. Y., Maric, I., Chaudry, S., Chang, Y. H., Smith, S. V., et al. (2001). GABA expression dominates neuronal lineage progression in the embryonic rat neocortex and facilitates neurite outgrowth via $\mathrm{GABA}_{\mathrm{A}}$ autoreceptor/ $/ \mathrm{Cl}^{-}$ channels. J. Neurosci. 21, 2343-2360. doi: 10.1523/jneurosci.21-07-02343.2001

Maroof, A. M., Keros, S., Tyson, J. A., Ying, S. W., Ganat, Y. M., Merkle, F. T., et al. (2013). Directed differentiation and functional maturation of cortical interneurons from human embryonic stem cells. Cell Stem Cell 12, 559-572. doi: 10.1016/j.stem.2013.04.008

Meredith, R. M. (2015). Sensitive and critical periods during neurotypical and aberrant neurodevelopment: a framework for neurodevelopmental disorders. Neurosci. Biobehav. Rev. 50, 180-188. doi: 10.1016/j.neubiorev.2014.12.001

Mertens, J., Paquola, A. C. M., Ku, M., Hatch, E., Böhnke, L., Ladjevardi, S., et al. (2015). Directly reprogrammed human neurons retain aging-associated transcriptomic signatures and reveal age-related nucleocytoplasmic defects. Cell Stem Cell 17, 705-718. doi: 10.1016/j.stem.2015.09.001

Métin, C., Denizot, J. P., and Ropert, N. (2000). Intermediate zone cells express calcium-permeable AMPA receptors and establish close contact with growing axons. J. Neurosci. 20, 696-708. doi: 10.1523/jneurosci.20-02-00696.2000

Mochizuki, N., Takagi, N., Kurokawa, K., Kawai, T., Besshoh, S., Tanonaka, K., et al. (2007). Effect of NMDA receptor antagonist on proliferation of neurospheres from embryonic brain. Neurosci. Lett. 417, 143-148. doi: 10.1016/j.neulet.2007.02.066

Monk, C. S., Peltier, S. J., Wiggins, J. L., Weng, S., Carrasco, M., Risi, S., et al. (2009). Abnormalities of intrinsic functional connectivity in ASD. Neuroimage 47, 764-772. doi: 10.1016/j.neuroimage.2009.04.069

Morales, M., and Bloom, F. E. (1997). The 5-HT3 receptor is present in different subpopulations of GABAergic neurons in the rat telencephalon. J. Neurosci. 17, 3157-3167. doi: 10.1523/jneurosci.17-09-03157.1997

Morelli, G., Avila, A., Ravanidis, S., Aourz, N., Neve, R. L., Smolders, I., et al. (2017). Cerebral cortical circuitry formation requires functional glycine receptors. Cereb. Cortex 27, 1863-1877. doi: 10.1093/cercor/bhw025

Murthy, S., Niquille, M., Hurni, N., Limoni, G., Frazer, S., Chameau, P., et al. (2014). Serotonin receptor 3A controls interneuron migration into the neocortex. Nat. Commun. 5:5524. doi: 10.1038/ncomms6524 
Nácher, J., Varea, E., Miguel Blasco-Ibáñez, J., Gómez-Climent, M. Á., CastilloGómez, E., Crespo, C., et al. (2007). N-methyl-d-aspartate receptor expression during adult neurogenesis in the rat dentate gyrus. Neuroscience 144, 855-864. doi: 10.1016/j.neuroscience.2006.10.021

Nageshappa, S., Carromeu, C., Trujillo, C. A., Mesci, P., Espuny-Camacho, I., Pasciuto, E., et al. (2016). Altered neuronal network and rescue in a human MECP2 duplication model. Mol. Psychiatry 21, 178-188. doi: 10.1038/mp. 2015.128

Nagy, J., Kobolák, J., Berzsenyi, S., Ábrahám, Z., Avci, H. X., Bock, I., et al. (2017). Altered neurite morphology and cholinergic function of induced pluripotent stem cell-derived neurons from a patient with Kleefstra syndrome and autism. Transl. Psychiatry 7:e1179. doi: 10.1038/tp.2017.144

Nestor, M. W., Phillips, A. W., Artimovich, E., Nestor, J. E., Hussman, J. P., and Blatt, G. J. (2016). Human inducible pluripotent stem cells and autism spectrum disorder: emerging technologies. Autism Res. 9, 513-535. doi: 10.1002/aur.1570

Nimmervoll, B., Denter, D. G., Sava, I., Kilb, W., and Luhmann, H. J. (2011). Glycine receptors influence radial migration in the embryonic mouse neocortex. Neuroreport 22, 509-513. doi: 10.1097/wnr.0b013e328348aafe

Noctor, S. C., Martínez-Cerdeño, V., Ivic, L., and Kriegstein, A. R. (2004). Cortical neurons arise in symmetric and asymmetric division zones and migrate through specific phases. Nat. Neurosci. 7, 136-144. doi: 10.1038/nn1172

Park, I.-H., Arora, N., Huo, H., Maherali, N., Ahfeldt, T., Shimamura, A., et al. (2008). Disease-specific induced pluripotent stem cells. Cell 134, 877-886. doi: 10.1016/j.cell.2008.07.041

Pașca, S. P. (2019). Assembling human brain organoids. Science 363, 126-127. doi: $10.1126 /$ science.aau5729

Paşca, A. M., Sloan, S. A., Clarke, L. E., Tian, Y., Makinson, C. D., Huber, N., et al. (2015). Functional cortical neurons and astrocytes from human pluripotent stem cells in 3D culture. Nat. Methods 12, 671-678. doi: 10.1038/nmeth.3415

Persoon, C. M., Moro, A., Nassal, J. P., Farina, M., Broeke, J. H., Arora, S., et al. (2018). Pool size estimations for dense-core vesicles in mammalian CNS neurons. EMBO J. 37:e99672. doi: 10.15252/embj.201899672

Platel, J.-C., Boisseau, S., Dupuis, A., Brocard, J., Poupard, A., Savasta, M., et al. (2005). $\mathrm{Na}+$ channel-mediated $\mathrm{Ca}^{2+}$ entry leads to glutamate secretion in mouse neocortical preplate. Proc. Natl. Acad. Sci. U S A 102, 19174-19179. doi: 10.1073/pnas.0504540102

Poulsen, F. R., Blaabjerg, M., Montero, M., and Zimmer, J. (2005). Glutamate receptor antagonists and growth factors modulate dentate granule cell neurogenesis in organotypic, rat hippocampal slice cultures. Brain Res. 1051, 35-49. doi: 10.1016/j.brainres.2005.05.050

Prè, D., Nestor, M. W., Sproul, A. A., Jacob, S., Koppensteiner, P., Chinchalongporn, V., et al. (2014). A time course analysis of the electrophysiological properties of neurons differentiated from human induced Pluripotent Stem Cells (iPSCs). PLoS One 9:e103418. doi: 10.1371/journal. pone. 0103418

Prilutsky, D., Palmer, N. P., Smedemark-Margulies, N., Schlaeger, T. M., Margulies, D. M., and Kohane, I. S. (2014). IPSC-derived neurons as a higherthroughput readout for autism: promises and pitfalls. Trends Mol. Med. 20, 91-104. doi: 10.1016/j.molmed.2013.11.004

Qian, T., Chen, R., Nakamura, M., Furukawa, T., Kumada, T., Akita, T., et al. (2014). Activity-dependent endogenous taurine release facilitates excitatory neurotransmission in the neocortical marginal zone of neonatal rats. Front. Cell. Neurosci. 8:33. doi: 10.3389/fncel.2014.00033

Qian, X., Jacob, F., Song, M. M., Nguyen, H. N., Song, H., and Ming, G.L. (2018). Generation of human brain region-specific organoids using a miniaturized spinning bioreactor. Nat. Protoc. 13, 565-580. doi: 10.1038/nprot. 2017.152

Qian, X., Nguyen, H. N., Song, M. M., Hadiono, C., Ogden, S. C., Hammack, C., et al. (2016). Brain-region-specific organoids using mini-bioreactors for modeling ZIKV exposure. Cell 165, 1238-1254. doi: 10.1016/j.cell.2016. 04.032

Qian, X., Song, H., and Ming, G. (2019). Brain organoids: advances, applications and challenges. Development 146:dev166074. doi: 10.1242/dev.166074

Qiang, L., Fujita, R., Yamashita, T., Angulo, S., Rhinn, H., Rhee, D., et al. (2011). Directed conversion of Alzheimer's disease patient skin fibroblasts into functional neurons. Cell 146, 359-371. doi: 10.1016/j.cell.2011.07.007

Quadrato, G., Nguyen, T., Macosko, E. Z., Sherwood, J. L., Min Yang, S., Berger, D. R., et al. (2017). Cell diversity and network dynamics in photosensitive human brain organoids. Nature 545, 48-53. doi: 10.1038/nature22047

Renner, M., Lancaster, M. A., Bian, S., Choi, H., Ku, T., Peer, A., et al. (2017). Selforganized developmental patterning and differentiation in cerebral organoids. EMBO J. 36, 1316-1329. doi: 10.15252/embj.201694700

Riccio, O., Jacobshagen, M., Golding, B., Vutskits, L., Jabaudon, D., Hornung, J. P., et al. (2011). Excess of serotonin affects neocortical pyramidal neuron migration. Transl. Psychiatry 1:e47. doi: 10.1038/tp.2011.49

Riccio, O., Potter, G., Walzer, C., Vallet, P., Szabó, G., Vutskits, L., et al. (2009). Excess of serotonin affects embryonic interneuron migration through activation of the serotonin receptor 6. Mol. Psychiatry 14, 280-290. doi: $10.1038 / \mathrm{mp} .2008 .89$

Rizo, J., and Südhof, T. C. (2012). The membrane fusion enigma: SNAREs, Sec1/Munc18 proteins, and their accomplices-guilty as charged? Annu. Rev. Cell Dev. Biol. 28, 279-308. doi: 10.1146/annurev-cellbio-101011-155818

Sakaguchi, H., Ozaki, Y., Ashida, T., Matsubara, T., Oishi, N., Kihara, S., et al. (2019). Self-organized synchronous calcium transients in a cultured human neural network derived from cerebral organoids. Stem Cell Reports 13, 458-473. doi: 10.1016/j.stemcr.2019.05.029

Sandoe, J., and Eggan, K. (2013). Opportunities and challenges of pluripotent stem cell neurodegenerative disease models. Nat. Neurosci. 16, 780-789. doi: $10.1038 / \mathrm{nn} .3425$

Scain, A.-L., Le Corronc, H., Allain, A.-E., Muller, E., Rigo, J.-M., Meyrand, P., et al. (2010). Glycine release from radial cells modulates the spontaneous activity and its propagation during early spinal cord development. J. Neurosci. 30, 390-403. doi: 10.1523/JNEUROSCI.2115-09.2010

Schafer, S. T., Paquola, A. C. M., Stern, S., Gosselin, D., Ku, M., Pena, M. et al. (2019). Pathological priming causes developmental gene network heterochronicity in autistic subject-derived neurons. Nat. Neurosci. 22, 243-255. doi: 10.1038/s41593-018-0295-x

Setia, H., and Muotri, A. R. (2019). Brain organoids as a model system for human neurodevelopment and disease. Semin. Cell Dev. Biol. doi: 10.1016/j.semcdb. 2019.03.002 [Epub ahead of print].

Shah, S. B., and Singh, A. (2017). Cellular self-assembly and biomaterials-based organoid models of development and diseases. Acta Biomater. 53, 29-45. doi: 10.1016/j.actbio.2017.01.075

Shcheglovitov, A., Shcheglovitova, O., Yazawa, M., Portmann, T., Shu, R., Sebastiano, V., et al. (2013). SHANK3 and IGF1 restore synaptic deficits in neurons from 22q13 deletion syndrome patients. Nature 503, 267-271. doi: $10.1038 /$ nature12618

Silva, C. G., Peyre, E., and Nguyen, L. (2019). Cell migration promotes dynamic cellular interactions to control cerebral cortex morphogenesis. Nat. Rev. Neurosci. 20, 318-329. doi: 10.1038/s41583-019-0148-y

Singh, A., Nikkhah, M., and Annabi, N. (2019). Biomaterials, cells, and pathophysiology: building better organoids and on-chip technologies. Biomaterials 198, 1-2. doi: 10.1016/j.biomaterials.2019.02.011

Sloan, S. A., Andersen, J., Pasca, A. M., Birey, F., and Pasca, S. P. (2018). Generation and assembly of human brain region-specific three-dimensional cultures. Nat. Protoc. 13, 2062-2085. doi: 10.1038/s41596-018-0032-7

Snyder, S. H. (2009). Neurotransmitters, receptors, and second messengers galore in 40 years. J. Neurosci. 29, 12717-12721. doi: 10.1523/JNEUROSCI.367009.2009

Song, M., Mohamad, O., Chen, D., and Yu, S. P. (2012). Coordinated development of voltage-gated $\mathrm{Na}^{+}$and $\mathrm{K}^{+}$currents regulates functional maturation of forebrain neurons derived from human induced pluripotent stem cells. Stem Cells Dev. 22, 1551-1563. doi: 10.1089/scd.2012.0556

Soria, J. M., and Valdeolmillos, M. (2002). Receptor-activated calcium signals in tangentially migrating cortical cells. Cereb. Cortex 12, 831-839. doi: $10.1093 /$ cercor/12.8.831

Stiles, J., and Jernigan, T. L. (2010). The basics of brain development. Neuropsychol. Rev. 20, 327-348. doi: 10.1007/s11065-010-9148-4

Südhof, T. C. (2013). Neurotransmitter release: the last millisecond in the life of a synaptic vesicle. Neuron 80, 675-690. doi: 10.1016/j.neuron.2013. 10.022

Takemoto-Kimura, S., Ageta-Ishihara, N., Nonaka, M., Adachi-Morishima, A., Mano, T., Okamura, M., et al. (2007). Regulation of dendritogenesis via a lipid-raft-associated $\mathrm{Ca}^{2+} /$ calmodulin-dependent protein kinase CLICKIII/CaMKI $\gamma$. Neuron 54, 755-770. doi: 10.1016/j.neuron.2007.05.021 
Tang, X., Kim, J., Zhou, L., Wengert, E., Zhang, L., Wu, Z., et al. (2016). KCC2 rescues functional deficits in human neurons derived from patients with Rett syndrome. Proc. Natl. Acad. Sci. U S A 113, 751-756. doi: 10.1073/pnas. 1524013113

Tang, X., Zhou, L., Wagner, A. M., Marchetto, M. C. N., Muotri, A. R., Gage, F. H., et al. (2013). Astroglial cells regulate the developmental timeline of human neurons differentiated from induced pluripotent stem cells. Stem Cell Res. 11, 743-757. doi: 10.1016/j.scr.2013.05.002

Tau, G. Z., and Peterson, B. S. (2010). Normal development of brain circuits. Neuropsychopharmacology 35, 147-168. doi: 10.1038/npp.2009.115

Tecott, L., Shtrom, S., and Julius, D. (1995). Expression of a serotonin-gated ion channel in embryonic neural and nonneural tissues. Mol. Cell. Neurosci. 6, 43-55. doi: 10.1006/mcne.1995.1005

Trujillo, C. A., Gao, R., Negraes, P. D., Gu, J., Buchanan, J., Preissel, S., et al. (2019). Complex oscillatory waves emerging from cortical short article complex oscillatory waves emerging from cortical. Cell Stem 25, 558.e7-569.e7. doi: 10.1016/j.stem.2019.08.002

Vangipuram, S. D., and Lyman, W. D. (2010). Ethanol alters cell fate of fetal human brain-derived stem and progenitor cells. Alcohol. Clin. Exp. Res. 34, 1574-1583. doi: 10.1111/j.1530-0277.2010.01242.x

Velasco, S., Kedaigle, A. J., Simmons, S. K., Nash, A., Rocha, M., Quadrato, G., et al. (2019). Individual brain organoids reproducibly form cell diversity of the human cerebral cortex. Nature 570, 523-527. doi: 10.1038/s41586-0191289-x

Verhage, M., Maia, A. S., Plomp, J. J., Brussaard, A. B., Heeroma, J. H., Vermeer, H., et al. (2000). Synaptic assembly of the brain in the absence of neurotransmitter secretion. Science 287, 864-869. doi: 10.1126/science.287. 5454.864

Vitalis, T., Cases, O., Passemard, S., Callebert, J., and Parnavelas, J. G. (2007). Embryonic depletion of serotonin affects cortical development. Eur. J. Neurosci. 26, 331-344. doi: 10.1111/j.1460-9568.2007.05661.x

Vitalis, T., and Parnavelas, J. G. (2003). The role of serotonin in early cortical development. Dev. Neurosci. 25, 245-256. doi: 10.1159/000072272

Vitrac, A., and Cloëz-Tayarani, I. (2018). Induced pluripotent stem cells as a tool to study brain circuits in autism-related disorders. Stem Cell Res. Ther. 9:226. doi: 10.1186/s13287-018-0966-2

Wang, S., Du, L., Peng, G., and Li, W. (2019). GABA inhibits proliferation and self-renewal of mouse retinal progenitor cell. Cell Death Discov. 5:80. doi: 10.1038/s41420-019-0160-Z

Wang, D. D., Krueger, D. D., and Bordey, A. (2003). GABA depolarizes neuronal progenitors of the postnatal subventricular zone via $\mathrm{GABA}_{\mathrm{A}}$ receptor activation. J. Physiol. 550, 785-800. doi: 10.1113/jphysiol.2003.042572

Wang, C., Liu, F., Patterson, T. A., Paule, M. G., and Slikker, W. (2017). Relationship between ketamine-induced developmental neurotoxicity and NMDA receptor-mediated calcium influx in neural stem cell-derived neurons. Neurotoxicology 60, 254-259. doi: 10.1016/j.neuro.2016.04.015
Whitney, N. P., Peng, H., Erdmann, N. B., Tian, C., Monaghan, D. T., and Zheng, J. C. (2008). Calcium-permeable AMPA receptors containing Q/R-unedited GluR2 direct human neural progenitor cell differentiation to neurons. FASEB J. 22, 2888-2900. doi: 10.1096/fj. 07-104661

Xiang, Y., Tanaka, Y., Patterson, B., Kang, Y. J., Govindaiah, G., Roselaar, N., et al. (2017). Fusion of regionally specified hPSC-derived organoids models human brain development and interneuron migration. Cell Stem Cell 21, 383.e7-398.e7. doi: 10.1016/j.stem.2017.07.007

Yakoub, A. M. (2019). Cerebral organoids exhibit mature neurons and astrocytes and recapitulate electrophysiological activity of the human brain. Neural Regen. Res. 14, 757-761. doi: 10.4103/1673-5374. 249283

Yi, F., Danko, T., Botelho, S. C., Patzke, C., Pak, C., Wernig, M., et al. (2016). Autism-associated SHANK3 haploinsufficiency causes Ih channelopathy in human neurons. Science 352:aaf2669. doi: 10.1126/science. aaf2669

Young-Pearse, T. L., Ivic, L., Kriegstein, A. R., and Cepko, C. L. (2006). Characterization of mice with targeted deletion of glycine receptor $\alpha 2$. Mol. Cell. Biol. 26, 5728-5734. doi: 10.1128/mcb.00237-06

Yuryev, M., Andriichuk, L., Leiwe, M., Jokinen, V., Carabalona, A., and Rivera, C. (2018). In vivo two-photon imaging of the embryonic cortex reveals spontaneous ketamine-sensitive calcium activity. Sci. Rep. 8:16059. doi: 10.1038/s41598-018-34410-x

Zaslavsky, K., Zhang, W.-B., McCready, F. P., Rodrigues, D. C., Deneault, E., Loo, C., et al. (2019). SHANK2 mutations associated with autism spectrum disorder cause hyperconnectivity of human neurons. Nat. Neurosci. 22, 556-564. doi: 10.1038/s41593-019-0365-8

Zhang, Y., Pak, C. H., Han, Y., Ahlenius, H., Zhang, Z., Chanda, S., et al. (2013). Rapid single-step induction of functional neurons from human pluripotent stem cells. Neuron 78, 785-798. doi: 10.1016/j.neuron.2013. 05.029

Zhong, S., Zhang, S., Fan, X., Wu, Q., Yan, L., Dong, J., et al. (2018). A single-cell RNA-seq survey of the developmental landscape of the human prefrontal cortex. Nature 555, 524-528. doi: 10.1038/nature25980

Conflict of Interest: The authors declare that the research was conducted in the absence of any commercial or financial relationships that could be construed as a potential conflict of interest.

Copyright (C) 2019 Ojeda and Ávila. This is an open-access article distributed under the terms of the Creative Commons Attribution License (CC BY). The use, distribution or reproduction in other forums is permitted, provided the original author(s) and the copyright owner(s) are credited and that the original publication in this journal is cited, in accordance with accepted academic practice. No use, distribution or reproduction is permitted which does not comply with these terms. 